\title{
How Fast is Money Growing?
}

\author{
by NORMAN N. BOWSHER
}

\begin{abstract}
Concern has been expressed about the progress this nation is making in the struggle against inflation. In recent months money has been rising at a very rapid pace. Experience has demonstrated that prolonged, rapid increases of money are followed by an excessive rise in spending and an intensification of inflation.
\end{abstract}

$\mathbb{R}$

ECOVERY FROM the slowdown of $1969-70$ has continued. Total spending has risen at a 7 per cent annual rate since the second quarter of 1970 , after a 4 per cent rate of increase in the three previous quarters. The growth rate in real output, adjusted for strikes and other irregular forces, has steadily increased since the first quarter of 1970. In the second quarter of this year, it is estimated that total spending is increasing at about a 10 per cent rate and real output is rising at about a 5 per cent rate. ${ }^{1}$

Retail sales have risen markedly since last November, following a two-year period of sluggishness, and housing starts have risen substantially since last fall. The composite of leading business indicators has risen at a 15 per cent annual rate since last September. Industrial production, after rebounding from the automobile strike, increased gradually in March and April. By contrast, industrial production declined about 3 per cent in the year preceding the strike.

Indications of the course of inflation are mixed. Consumer prices have risen at a 4 per cent annual rate since June of last year, compared with 6 per cent from mid-1969 to mid-1970. However, there has been little, if any, improvement in the wholesale sector. Average hourly earnings in manufacturing, adjusted for interindustry shifts and changes in overtime, have risen at an 8 per cent rate since last August, compared with a 6.4 per cent increase in the previous year.

Monetary restraint was applied in 1969 to reduce the inflationary pressures. During 1969, the money stock rose about 3 per cent, down from the 7.6 per cent rate of the previous two years. Growth in total spending slowed about six months later. After a still longer lag, the rate of advance in some price indicators began receding gradually.

1See the "Quarterly Economic Trends" release of this Bank, May 26,1971, p. 6 .
Since early 1970, monetary policies have been relaxed considerably. During 1970 money increased 5.4 per cent. Spending and production have been stimulated, despite the auto strike and cutbacks in Government defense spending. Early this year the growth rate in money again accelerated. Concern is developing over whether the rate of monetary expansion has become too rapid. ${ }^{2}$

This article discusses the recent rate of money growth and attempts to place it in some historical perspective. The accompanying note discusses some problems in measuring money growth.

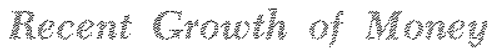

In the four months from January to May, the money stock rose at a 14 per cent annual rate to a level of about $\$ 224$ billion. The rapid rise did not depend on an unusual jump in any one month. On the contrary, month-to-month annual rates of increase were 15 per cent, 12 per cent, 10 per cent, and 18 per cent, respectively.

Since last November, money has risen at a 10 per cent annual rate and since September, at an 8 per cent rate. For the entire fifteen-month period from February last year, which began a marked and sustained increase in the rate of growth, to May this year, money grew at an average 7.6 per cent annual rate.

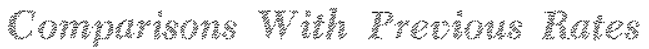

The recent rates of money expansion are relatively rapid compared with other periods since the early 1950 's. The 10 per cent annual rate since November, and the 7.6 per cent rate since February 1970 , compare with a 3 per cent rate from January 1969 to February 1970 , a previous period of a relatively

\footnotetext{
-See dissents in the "Record of Policy Actions of the Federal Open Market Committee," contained in the Federal Reserve Bulletin for February 1971, pp. 118.19; for April 1971, p.
} 327 ; and for May 1971 , p. 397. 
uniform growth rate in money. With the 3 per cent rate, total spending slowed to about a 5 per cent rate of growth, just slightly faster than the upward trend of productive capacity and perhaps near an optimum rate for the longer run. However, because of previous excesses, prices continued to rise rapidly at about the same rate as total spending, leaving total production nearly unchanged.
Money grew at a 5.8 per cent average rate from May 1965 to January 1969. Total spending on goods and services rose at a rapid 8 per cent anmual rate from 1965 to 1969. Since production was at near capacity levels, output was limited by growth in labor, capital, and technology, and prices were bid up at increasing rates. Overall prices, which had risen 1.5 per cent from 1963 to 1964 , rose 1.9 per cent from

\section{Some Prohlems in Measuring Money Growth}

Monetary developments have significant effects on spending, prodtiction, employment, nincomes, and prices. One neasure of monetary influence is the growth rate in the nation's money stock (private demand deposits and currency in the hands of the public). Measuring llow fast noney is currently lising and judging the appropriateness of that rate however, are not simple natters.

The appropriateness of a given rate of noney growth depends, in part, on the economic situation. Becatse the economy is now sluggish some analysts believe that money growth, no matter what the rate, has been too slow Others, focusing on inflation, believe that lhe growth rate of noney has been mueh too fast However most analysts feet a moderate policy course is more appropriate than either of these extrenes which focus on a single objective.

Some recommend a policy of stimulation so long as gains in current production and emplovment outweigh the increases in eurrent prices. However, value judgnents differ on the costs of inflation and idle resources, causing disagreements on the appropitate rate of monetary expansion. Still others emphasize the effect of lags; and find that a rate of noney growth acts with a longer lag on inflation that on employment. To them, the apparent paradox of anemployment with inflation may merely be an unavoidable transition from a period of excessive monetary expansion.

The noney supply fluctuates each day by as nuch as a billion dollars and more. Short-run flictuations may be caused by movements in total bank reserves, Treasury deposits, time deposits, and excess reserves, as well as by a number of other factors. Most of these dally novements are offset within a brief period by opposite short fun fluctuations. Daily Aluctuations in money probably have no significant eflect on aggregate spending, production, and prices, and daily data are not published regularly.

Data on money are collected, tabulated, and publistied on a daily averige basis, both seasonally adjusted and unadjusted, for weeks and for nonths. Compounded anmual tates of change for various combinations of be- ginning and ending periods are published by this Bank in order to facilitate comparisons:

Selecting a proper period for analysis is an important step in intepreting noney movernents. Ore-week or onemonth changes are quite iregular and seldom have been found to have a nessurable effect on spending, production, or prices: The ninimum period for meaningful analysis is usually about three monthis. Yet, arbitrarily pieking a three-nonth or one-year period may be quite misleading:

Experience indicates that selecting "good" base and ending periods for comparison is essential. 16eally, these points should nark the terminal points of a relatively inifom trend, or at least be on sach a trend. The boints selected should be free of significant bulges or dips, and if the ending period is the most recent data available, os is frequently the ease, then allowances should be made for possible revisions and for known infuences that are likely to be temporary. This is especially true where the period to be stidied is relatively short, since a given deviation affects rates of change nore over a short penod than when spread over a longer time span. On the other liand, if the period reviewed is tnduly long, meaningful shomer nun trends nay be lost.

Other considerations in selecting appropriate periods for measumg money growth nuy include policy intentions, movenents in related nunetary aggregates, and movenents in spending. prodiction, and priees. Then, 100, periods selected nay aiffer. depending on the use to be made of the data. For example, if the objeet is to evahuate the effectiveness of the Federal Reserve Systen in controlling noney, the period should be relatively short, say, about thee nonthis. If the object is to measure the impact of a given change in a money thend on a change in the rate of real produetion, a longer period would probably be desirable for the new tend, say about five months to a year If the object is to relete the growth of noney to the upward trend of prices, the appropiate period nay be a trend over several years.

ISee the tafistical release 116. Money Stoek Measures? and the Tederal Reserve Butedn publithed by the Board of

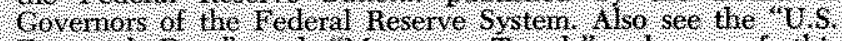
Tinancial bat's and Mondary Trends? releases of this Bark. 


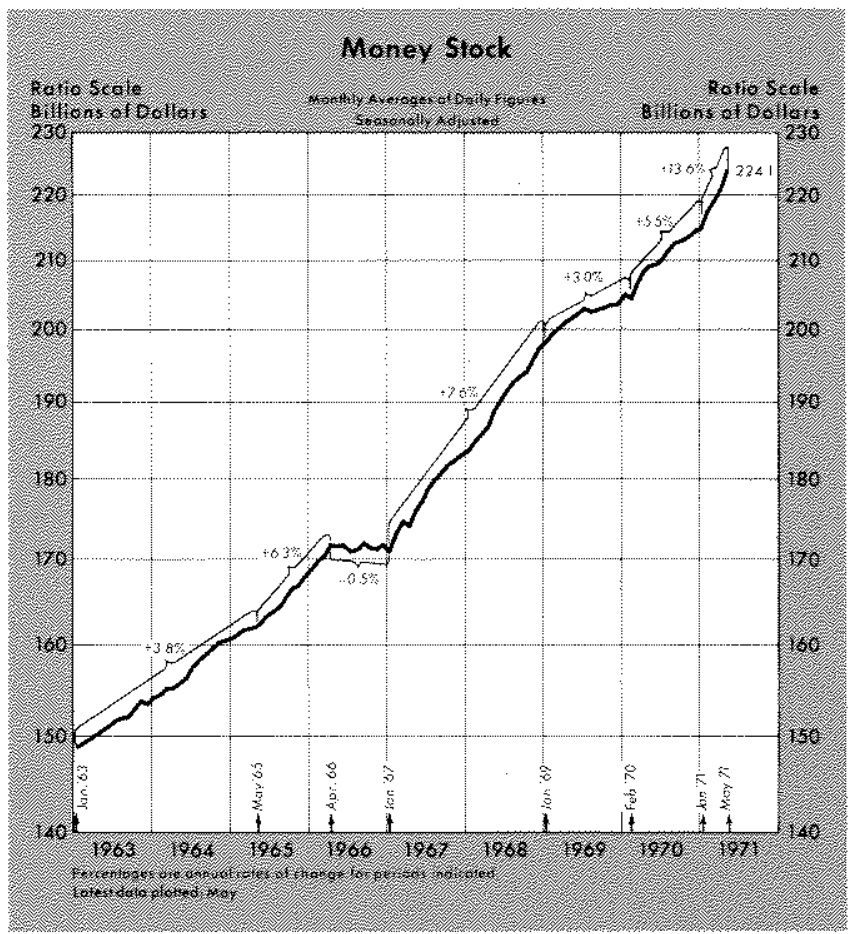

1964 to 1965 , and 2.7 per cent, 3.2 per cent, 4.0 per cent, 4.7 per cent, and 5.3 per cent, respectively, in successive years.

The trend growth in money was 2.3 per cent per year from 1951 to 1965 . This trend was sufficient to accommodate the growth in business and financial transactions caused by the expansion of real output.

\section{Compansons Whe Oner Teconery Periods}

The economy is now in the process of recovering from a mild recession. Some stimulation might be appropriate during a recession, but the 10 per cent rate of growth of money since last November is more rapid than during other recovery periods.

Recessions occurred in 1949, 1954, 1958, and 1960, and there was a marked slowing of activity in 1966-67. During the recession of 1949 , money growth accelerated, and from November 1949 to April 1953 money grew at a 4.3 per cent anmal rate. From April 1954 to May 1955 and from January 1958 to June 1959 , money again grew at the accelerated rate of 4.3 per cent. In each of these recessions, monetary actions were considered to be aggressively stimulative at the time; in each case the acceleration of money growth was followed within a few months by an upturn in the growth rate of spending and production. Also, inflation generally became stronger about a year later, and the rate of monetary expansion appeared, in retrospect, to have been too rapid.
Money growth accelerated again during the recession of 1960. The rate of money growth, begimning in 1960, was more moderate than those during the three earlier recovery periods, and was continued longer. Money, after declining from mid-1959 to mid-1960, rose at a 3 per cent average rate for about 5 years, from June 1960 to May 1965. The economic recovery after 1960 was less pronounced than after the three previous recessions, but the expansion occurred without great imbalances or an intensification of inflationary pressures. By late 1964 and early 1965, production was approaching the limits of capacity and expanding at near the maximum sustainable pace. The economy was then given an upward jolt by a sharp increase in Federal spending and the accompanying large monetary injections of 1965, 1967, and 1968.

During the slowdown in spending and production of late 1966 and early 1967, money growth accelerated to a 7.6 per cent annual rate, and this rate was maintained through 1968. Total spending spurted after about a six-month lag, and inflationary pressures intensified more quickly and to a greater extent than after any of the previous recessions.

\section{Percentive Comparisons}

Comparison of monetary increases in some recent periods - the last three months, the last six, the last nine, and the last twelve - with all earlier periods of similar length may provide additional insight into how rapid recent monetary growth has been. In the last three months, money has risen at a 13 per cent amial rate. This is in the 100 th percentile of all consecutive three-month periods since January 1950. In fact, money rose faster in both the January-to-April and the February-to-May 1971 periods than in any of the other 255 three-month periods.

In the last six months, money has risen at a 10 per cent amnual rate. This also is in the 100th percentile of all consecutive six-month periods since January 1950 . The 8 per cent rise in money over the last nine months places it in the 99 th percentile of all nine-month periods. The 7 per cent growth of money in the last twelve months is in the 95th percentile.

Sizable monetary injections might be appropriate under extremely depressed economic conditions for brief periods. At the present time, excess capacity in the nation is moderate, and price increases continue at near peak rates. Unemployment, which averaged 5.7 per cent in the last twelve months, was in the 79 th percentile of all twelve-month periods since January 
1950. Overall prices rose 5 per cent in the last four quarters, which is in the 90 th percentile of all fourquarter changes.

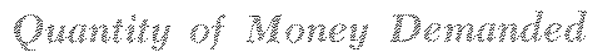

The supply of money should be just sufficient to accommodate increasing public desires to hold money as an asset when spending rises at a rate consistent with potential output. If money rises more rapidly than the amount demanded (given current interest rates, incomes, wealth, and other pertinent conditions), the public will tend to increase current expenditures in an attempt to reduce the excess cash balances. Conversely, if the money supply rises less rapidly than does the amount the public wishes to hold, they will decrease current expenditures in an attempt to build up cash balances.

The aggregate amount of money demanded cannot be measured precisely. Relating past changes in the money stock with the accompanying and lagged changes in spending is, in effect, a method for estimating the past growth in the demand for money to hold. Such studies indicate that the growth in money demanded in the United States has been relatively steady at about a 3 per cent annual rate since the late 1940 's. Whenever the money stock rose at a 2 per cent rate or slower for an extended period, economic activity tended to slow. On the other hand, whenever money rose at a 4 per cent rate or faster for an ex-

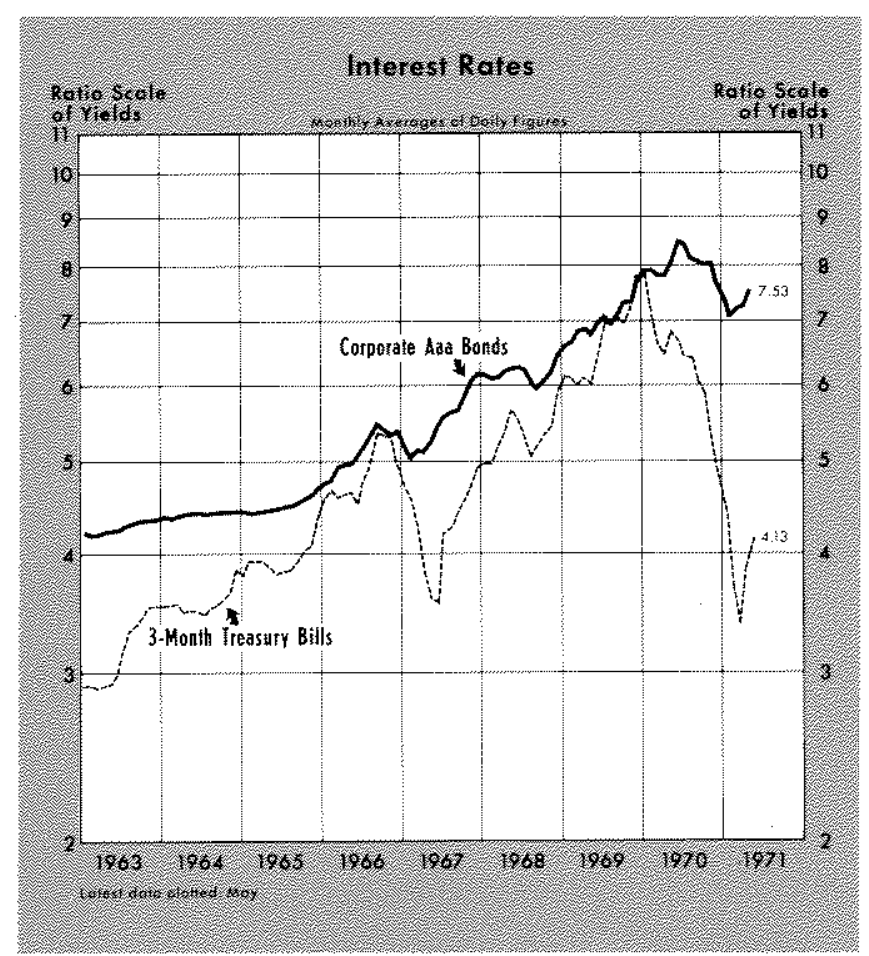

tended period, spending tended to rise more rapidly and, in time, price increases accelerated.

It is possible that the amount of money demanded has changed recently, so that earlier relationships no longer hold. Economic studies indicate that the amount of money demanded as an asset depends on a number of factors, particularly interest rates, real income and wealth, and prices, as well as the technology of minimizing cash balances.

Interest rates are currently at relatively high levels historically. Since an increase in interest rates raises the opportunity cost of holding money, the amount of money demanded has probably declined. A reversal occurred last fall and winter with the decline of interest rates from their peak levels, but most rates have risen again since March.

Real income has changed little since mid-1969. By comparison, the upward trend of real income was 4 per cent per year from 1957 to 1969 . With the slower growth of income (and wealth), other things equal, it might be expected that the growth in the amount of money demanded also has slowed.

Inflation has been strong in recent years, and inflation and inflationary expectations have several effects on the amount of money demanded. Since inflation

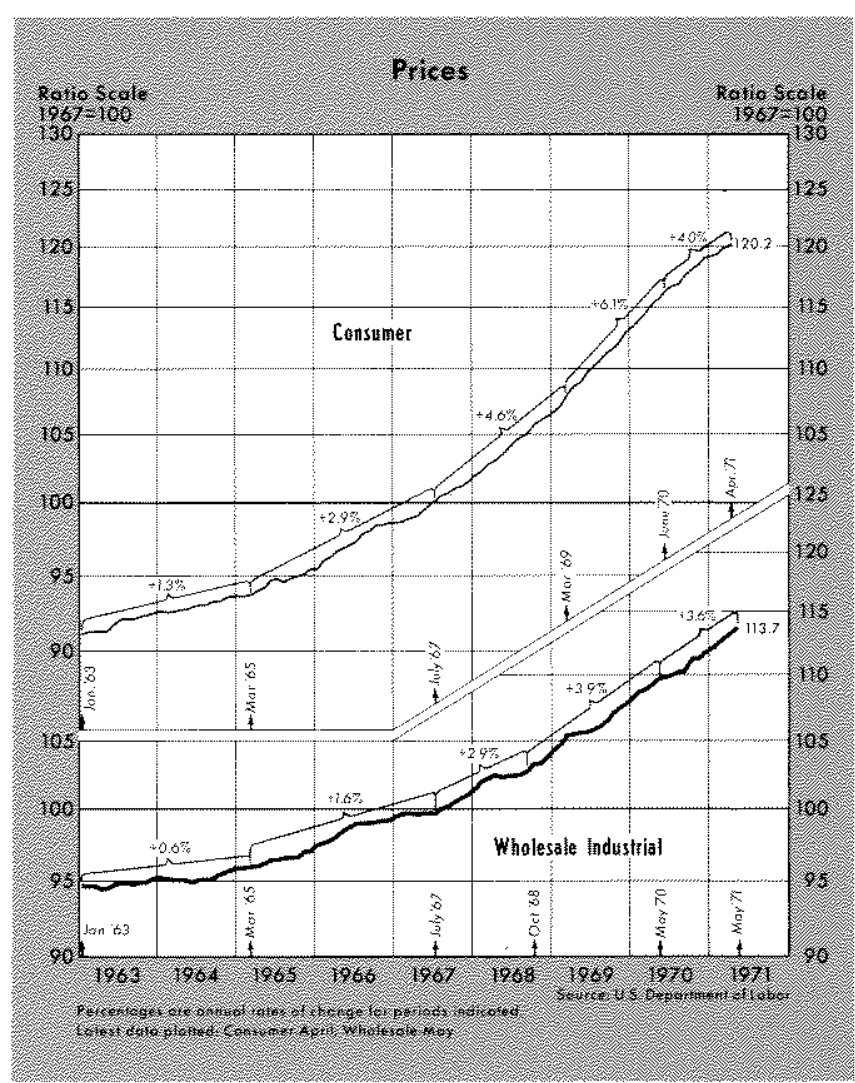


reduces the real value of money, the amount desired as a store of value declines. On the other hand, as prices for goods and services increase, the amount of money demanded by individuals and businesses for transactions probably rises. However, supplying money in response to an inflation-induced increase in the amount of money demanded tends to accommodate the inflation malady. The rate of inflation may have been gradually reeeding for about a year, slowing the increase in the amount of money demanded for transactions because of rising prices.

This review of recent developments in the forces thought to be most influential in determining the quantity of money demanded suggests that only little change has occurred in the trend of money demanded in the last year. If this is true, past relationships between the quantity of money supplied and the subsequent growth in spending can be expected to continue with little change. To the extent that there have been any changes in the past year, some acceleration in the growth in the amount of money demanded probably occurred in 1970 with the decline in market rates. More recently, most forces seem to be slowing the growth rate in the amount of money demanded, indicating that the growth rate of total spending will be faster in the near future relative to growth in the quantity of money supplied.

\section{Wong}

Evaluation of whether a rate of money growth is too rapid depends on the likely economic impact. Assuming a 9 per cent annual rate of money growth, which is slightly less than that experienced since last November, a very rapid economic expansion is likely in the near future. At this rate of monetary injection, this Bank's model indicates that growth in total spending for goods and services would accelerate from the recent 7 per cent annual rate to about a 10 or 11 per cent rate in the latter part of $1972.3^{3}$ Deviations of spending from the model projections seem more likely to occur on the high side than on the low. Typically, when money has risen very rapidly for an extended period, the growth in velocity of money also has risen after a two or three quarter lag." The model has not captured fully the increases of velocity in previous recovery periods.

\footnotetext{
"For cletails on the model, see "A Monetarist Model for Economic Stabilization," April 1970 Review of this Bank, pp. 7-25. For current projections of this model, see the "Quarterly Economic Trends" release of this Bank.

"See "Changes in the Velocity of Money," Reprint No. 4 of this Bank.
}

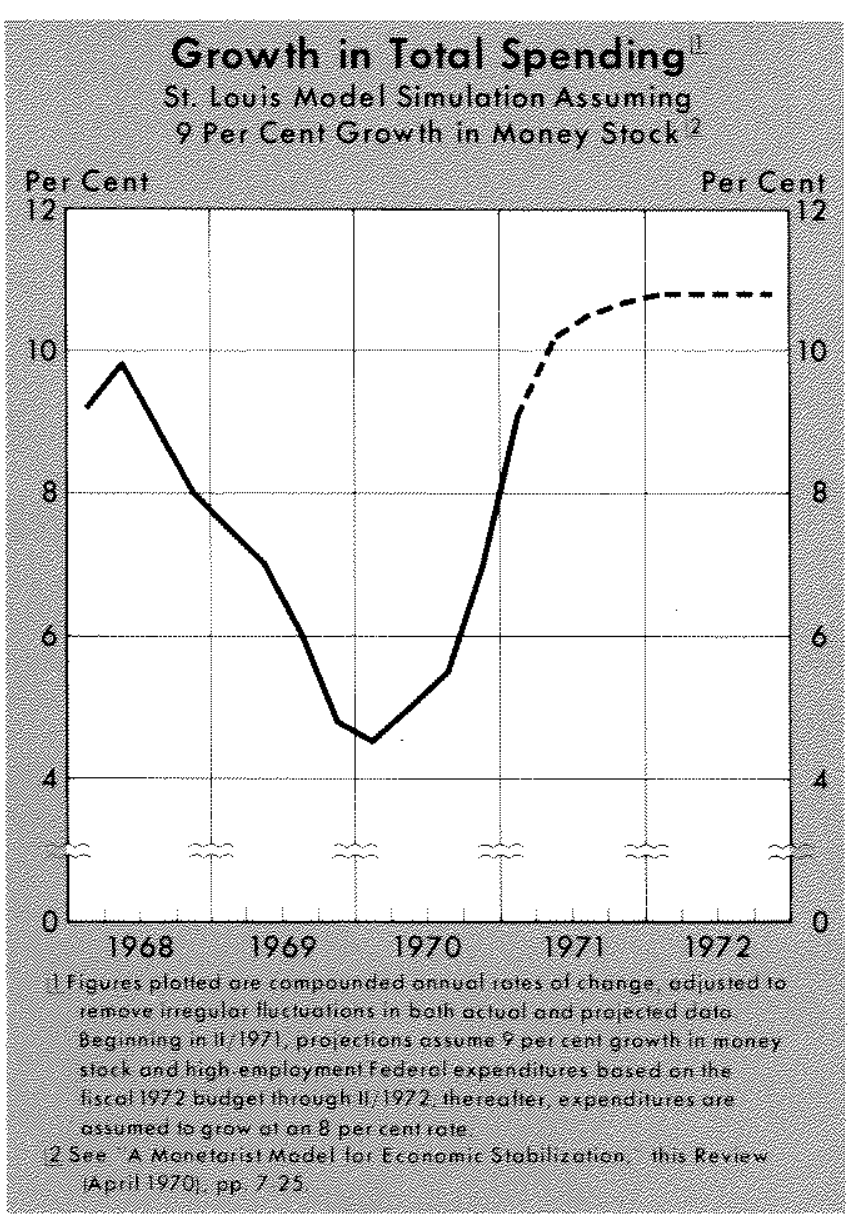

Growth in real product with a 9 per cent rate of increase of money would accelerate from the recent 1. per cent annual rate of increase to about a 6 per cent rate late next year, according to this Bank's model. This would be above a sustainable rate, given the trend growth of productive capacity, estimated to be about 4 per cent per year.

By utilizing idle resources, a greater-than-sustainable rate of production growth could be accommodated for a short period with the current rate of inflation changing little. The model indicates little or no increase in the rate of price advance for the next year and a half, even with the 9 per cent money growth. However, the model indicates that inflation would intensify markedly after 1972 under such a stimulative policy. Resisting inflation at a later time, then, would lead to greater costs in reduced output growth than presently.

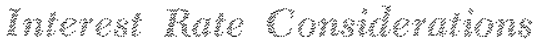

Although money has expanded sharply, most interest rates have risen in recent months. Interest rates on highest-grade corporate bonds rose from 7.1 per cent 


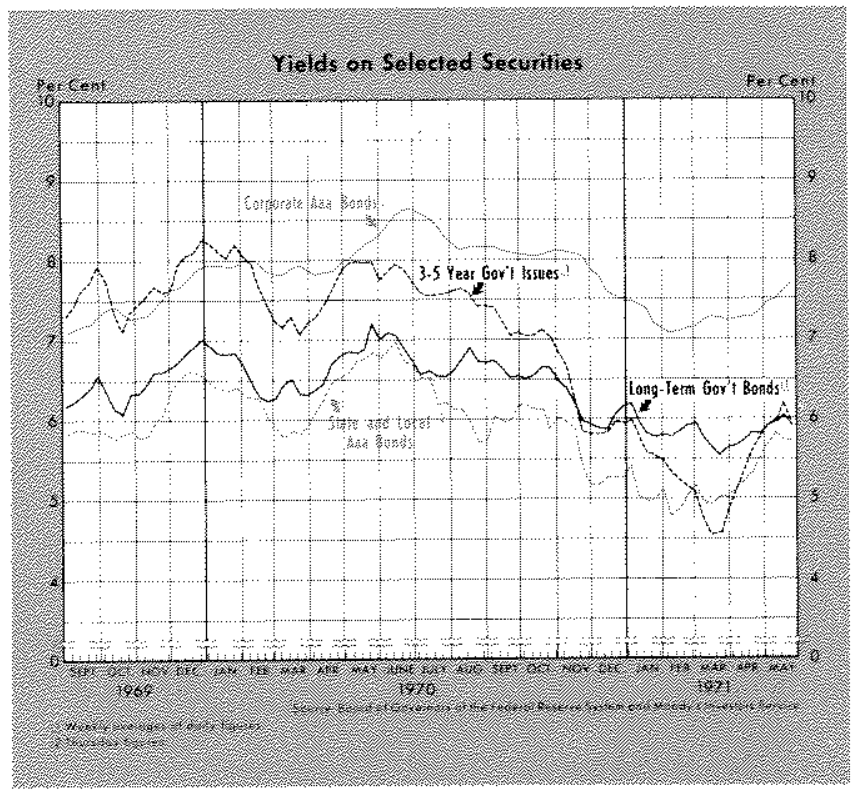

in February to 7.7 per cent in early June. Concern has been expressed that a rise in interest rates, particularly long-term rates, might choke off the economic recovery. ${ }^{\overline{3}}$

Market interest rates are the prices at which the quantity of credit supplied and the quantity demanded are equated. Monetary actions affect both the demand for and supply of credit. An increase in the stock of money and bank credit adds directly to the supply of loanable funds, tending to cause interest rates in the short run to be lower than they otherwise would be.

A rise in the money stock also has expansionary effects on the total demand for goods and services. When dollar balances and credit are increased rapidly, given existing assets, incomes, prices, and interest rates, the public attempts to exchange some of the "excess money" for goods and services. This tends, in time, to cause an increase in total spending, production, and prices. With expectations of greater sales and a higher rate of inflation, demands for credit may be expanded at a faster rate than the supply of credit created, and net upward pressure on interest rates results. The rise in rates in recent months is probably a reflection of a very rapid monetary stimulation of demands for credit rather than evidence of any monetary restraint.

"See Wall Street Journal, "Interest Rates Reverse Downward Trend; Stir Fears for the Economy," May 25, 1971, p. 1; and Ben Weberman, "Fed Baffed as to How to Get Rates Dowi3," American Banker, May 24, 1971, p. 1.

6 For additional analysis of the interaction of monetary actions, inflation, and interest rates, see "The Road to Accelerating Inflation is Paved with Good Intentions," in this Review; pp. 9.15 .
Interest rates perform a function in our economic system similar to that of prices of goods and services. They allocate scarce resources among competing users, but have little bearing on the level of total resource utilization. As such, high market interest rates should be viewed as having about the same implications for economic stabilization as higher market prices on commodities or services.

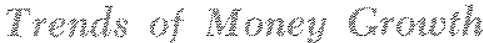

Additional perspective on the recent rate of money growth can be obtained by comparing trends over longer periods, covering several monetary cycles. From early 1952 to mid-1964, the money stock grew at an average 1.9 per cent average annual rate. Within this twelve and a half year period, several cyclical upswings in money growth occurred, and spending, production, and employment increased rapidly. At other times, the money stock drifted down relative to the trend, and, with a brief lag, spending and production slowed and unemployment rose. Overall prices in this period rose at a relatively slow 1.8 per cent annual rate.

Since mid-1964, money has risen at a faster 5.3 per cent average ammual rate. Early in the period, as money accelerated to the new trend, and later, as money moved up relative to the trend, spending. production, and employment received a temporary stimulus. But as money moved down relative to the trend, sluggishness and slack reappeared. The rate of overall price increase has accelerated from the 1.8 per cent rate of the Fifties and early Sixties to a 5.3 per cent rate since mid-1969.

Unemployment experience was about the same whether the trend growth of money was 1.9 per cent (1952-64) or 5.3 per cent (1964-71). Both trend periods contained some relatively high and some relatively low unemployment rates. The trend growth of money apparently had its chief impact on the trend of spending growth and the rate of price advance. It has been the shorter-run movements around the trends which have apparently had the greatest impact on cyclical changes in spending, production, and employment.

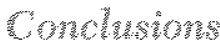

Recent growth rates of money have been very rapid, as measured in a number of ways. Experience has demonstrated that large, prolonged injections of money will be followed by an excessive rise in spending and an intensification of inflationary pressures. Largest increases of money have usually occurred 
during periods of economic slack for the purpose of stimulating spending, but from 1960 to early 1965 a balanced recovery and expansion occurred while money rose moderately. Experience also indicates that when money growth accelerates for a prolonged period and then ceases to accelerate, as it must if the economic system is to survive, growth in production slows and unemployment increases at higher rates of inflation.

Two lessons seem to emerge from the money experience of the past two decades. First, if the upward thrust of inflation is to be halted, the trend growth of money must be reduced to a moderate rate. The precise rate depends on the growth of money demanded under conditions of anticipated price stability (perhaps about a 3 or 4 per cent annual rate). However, money has risen rapidly in the last six months, raising slightly the growth trend of money for the past several years and indicating likely intensification of inflation in the near future if continued much longer.

Second, changes in the trend growth of money should be gradual, and short-run movements around the trend should be slight, because marked movements away from a previous trend have usually been followed by destabilizing changes in spending. The sharp money growth in recent months has deviated significantly upward from the previous trend, indicating a faster-than-sustainable rate of increase in production in the near future. 